\title{
Cannibalistic Imaginaries: Mining the \\ Natural and Social Body in Papua \\ New Guinea
}

Jamon Halvaksz

$\mathrm{I}_{\mathrm{n}}$

mages of cannibalism and gold permeate the history of the nation of Papua New Guinea. Various Spanish and Portuguese explorers named one or more of the islands while under the assumption that gold would be found among its alluvial deposits. In I 528, for instance, Alvaro de Saavedra dubbed the Schouten Islands along the Northwest coast of New Guinea "Isla de Oro" (Island of Gold). Later, Inigo Ortiz de Retes claimed the mainland for the Spanish monarchy, calling it "Nuevo Guinea." However, many found the mountainous jungles and its inhabitants inhospitable, and these islands became more widely known for their "Stone Age tribes" than for their stones. Over the years, despite its abundant production of mineral resources, highlighted by international court cases (Ok Tedi, for example) and internal strife (as witnessed on Bougainville), and the presence of some of the world's largest gold and copper mines, Papua New Guinea is still associated with the "primitive," the "unexpected," the Stone Age, and in its most extreme form, cannibalism. This raises the question: Why is it that mineral wealth is so overlooked in the way that many imagine this nation, while images of the primitive persist?

In his analysis of Venezuela's emergence as a modern postcolonial nation, Fernando Coronil discussed the relationship between natural resources and the creation of global and national imaginaries. He noted, "At the close of the twentieth century, Venezuela is commonly identified as an oil nation. Strange as this may seem, a mere material commodity serves to represent its identity as a national community. The remarkable fact that this rather common manner of identifying a neocolonial nation by its major export product seems unremarkably natural only highlights the need to understand why some nations have become so bonded to some

The Contemporary Pacific, Volume I8, Number 2, 335-359

(C) 2006 by University of Hawai'i Press 
commodities that they have come to be identified by them" (Coronil I997, 67). Such national images, Coronil wrote, require a certain historical amnesia about how they come into being. The particulars are forgotten, giving more authority to the ideal of an oil nation. Central to this merging of the political body (the Venezuelan state) with the natural body (oil) is the "domestication of value," whereby a commodity is converted into common currency and permeates society as exchange value. The value of oil is revealed in the degree to which nature can be, in Marshall Sahlins's phrase, "harnessed by culture to its own intentions" (I976, I96). The "primitive" state of Venezuela is thus converted into an oil state, as "oil money" permeates all transactions. Other examples exist both in the subsoil, with South African diamonds, and on the surface, with crops such as Brazilian or Columbian Coffee.

The national and global image of Papua New Guinea raises an alternative question. Mineral wealth permeates the national economy: while not evenly distributed, in the 2003 budget it accounted for 2 I percent of gross domestic product and 75 percent of national export earnings, and it continues to provide significant tax revenue for the state (Chand 2003). At the time of PNG independence in 1975, the defunct Bougainville Copper Mine was imagined as the future of the country. And while the era of large mines seems to be coming to a close, numerous smaller gold and copper projects throughout the nation continue to drive local aspirations. So why hasn't Papua New Guinea become so bonded to its commodities? Following Coronil, answering this question requires us to consider under what historical conditions the nation's mineral wealth entered into the national and global imaginary. ${ }^{1}$ Are the particulars perhaps not forgotten? And, more specifically, what environmental and economic regimes operate to maintain its salience?

Cannibalism and gold remain powerful images for the Biangai of the Upper Bulolo Valley in the country's Morobe Province. The Biangai are the customary landholders in the area of the Edie Creek gold rush of the I920s. My doctoral research compared the experiences of Winima villagers, on whose land the Hidden Valley gold mine is now being developed, with those of Elauru villagers, whose land is outside the mining lease. ${ }^{2}$ Our conversations over seventeen months of fieldwork focused on how they encounter development. ${ }^{3}$ For both groups, cannibalistic images are entangled in discourses about current gold mining. Here, I examine the contours of this relationship as the practices of gold mining differently articulate with the local population. My focus is not so much on the political body - the state-as it is on the creation of meanings within this 
location and within a particular social body-the Biangai communities around Wau. Like Coronil, I argue that the social and natural bodies do emerge together in the national imaginary. However, the value that is produced, domesticated, and circulated is not mineral wealth, but an imperfect hybrid of gold and a naturalized "other." Both might be glossed as forms of consumption that transform the social and physical landscape into particular kinds of sociality. In some ways, it is no surprise, nor is it unique to Papua New Guinea, that cannibalistic images are entangled in discourses about gold mining, as in Western discourses both are associated with greed and violence (consider, for example, the ill-fated Donner party parodied in Charlie Chaplin's 1925 film, The Gold Rush). For Papua New Guinea, I argue, gold and cannibalism are coupled together in the spaces left by the inconsistent revenue and benefit streams associated with gold mining and the international markets that set the price. These gaps allow for a different articulation of the natural and social body. In the place of pure gold, we find cannibal-gold and the Stone Age tribe.

\section{Theorizing the Cannibal}

It has been noted that cannibalism is one of the most extreme forms for creating a moral distance from the "other" (see, eg, Arens 1979; Goldman I999). Within anthropology, cannibalism continues to be a much-debated topic (Lindenbaum 2004). However, the focus is not so much on the interpretation and local meaning of such practices as it is on whether or not the practice ever existed. Despite numerous anthropological discussions (see, eg, volumes edited by Brown and Tuzin [1983] and Goldman [1999]), no anthropologist can claim to have witnessed it firsthand. Furthermore, it is often asserted that eyewitness accounts by missionaries, people on exploration vessels, colonial officers, and others are highly questionable (see, eg, Arens 1979; Dixon 200I; Obeyesekere 1992). Instead, William Arens and others have argued that these accounts are rooted in colonial ideas of the other, establishing the ultimate in ethnographic difference, and granting moral authority to colonial representatives.

In an extension of his ongoing dispute with Sahlins, Gananath Obeyesekere has further argued, "The discourse on cannibalism tells us more about the British preoccupation with cannibalism than about Maori cannibalism" (I992, 69I), or Fijian cannibalism (Obeyesekere 1998, 200I), or, we might add, Papua New Guinean cannibalism. Certainly, there is merit in this point (Tuzin and Brown 1983, 3). In Papua New Guinea, for instance, is it a mere coincidence that cannibalism coincides with the 
demarcation of "uncontrolled areas," follows gold prospectors inland, and vanishes once the colonial administration is established? However, in our zeal to deconstruct the historical record, we cannot ignore local conceptualizations. As Laurence R Goldman argued in his introduction to a I999 volume on the subject, "imaginative literature and sacred histories are mutually implicative, and mutually referential dialogues, not polarized fields of symbolic reasoning" ( 1999,3$)$. In what ways do different ideas of cannibalism, both indigenous and colonial, "speak" to one another over space and time?

Cannibalism's intersection with gold and gold mining, both past and present, reveals that these are not only "mutually referential dialogues" (Goldman 1999,3 ), but that they continue to circulate in debates about development and are active in global images of the nation. Here, I uncover a history of cannibalism and mineral wealth (particularly gold) that illustrates how one came to stand for local desires and national imaginings, and the other did not.

For early gold prospectors along the Bulolo River, fending off cannibals was a central trope of the experience. As they succeeded in conquering the landscape, winning gold from its surfaces, they also succeeded in protecting themselves from the people whose lands they treated as "waste and vacant." When early miners first entered Biangai lands, before there was a town called Wau, or creeks and streams named by prospectors, they positioned themselves in contrast to the local population, whose supposed penchant for consuming flesh was well advertised in the Australian newspapers. For the Biangai of the Wau-Bulolo Valley, cannibalism and gold continue to be pervasive themes in their development imaginaries. The local discourse around capitalist development, and especially gold mining, depicts Biangai ideas of cannibalism as obstructing contemporary development (gold mining, coffee plantations, etc). Polluted by cannibalism's transgressions, the land and its spiritual occupants refuse to be productive. The relationship between these images of gold and cannibalism, I argue, is formative in the global images of Papua New Guinea.

In what follows, I examine two distinct lines in this cannibalistic imaginary. The first emerges out of the personal experiences of an early prospector, recounted by Doris R Booth in her I929 travelogue, Mountains, Gold and Cannibals. This discussion leads into an analysis of a series of events collectively known as the "Kaisenik Killings," which represent a shift in the relationship between miners and Biangai as the colonial administration engaged in punitive expeditions to bring the accused cannibals under control. The second line follows contemporary Biangai engage- 
ments with cannibalism and gold, highlighting the ongoing significance of this imaginary in local practice.

\section{Colonial Gold Mining}

Arthur Darling discovered gold in the small streams around Wau in I9ro. Although he died before he could return to stake his claim, he reportedly told William "Sharkeye" Park of his discovery. Park and his partner, Jack Nettleton, eventually found Darling's discovery in April I922. Given the remote location and the relative size of the find, a major gold rush was held in check (Healy 1967, I7). With Bill Royal and Dick Glasson's discovery of the Edie Creek and Koranga deposits in January 1926, the Australian press began to advertise the rich but difficult field in central New Guinea. By mid-I926, 2 I9 white miners and I,324 coastal laborers had invaded the Wau-Bulolo Valley (Sinclair 1998, 42). The appearance of whites, their laborers, and the resources at their disposal revealed to the Biangai the existence of a much wider geography, and the Biangai continue to manipulate these differences as they find their way into the global economy. In the early days of gold exploration along the Bulolo during the I920s, the Biangai were more than reticent to become carriers for the growing mining community, demonstrating a reluctance to work (Booth I929; see also below); some were in direct conflict with miners and their indentured laborers over the theft of produce and pigs from Biangai gardens (Willis 1977a, 1977b). Gold miners struggled, both to maintain successful mining operations in what they viewed to be the harshest and most wild of conditions, and to protect themselves from those whom they believed to be cannibals.

Numerous accounts promulgated the ideas of cannibalism and gold through travelogues and feature-length newspaper articles. ${ }^{4}$ Besides Booth's travelogue, Frank Clune's Somewhere in New Guinea (1952), Edmund Demaitre's New Guinea Gold (1936), and Ion Llewellyn Idriess's Gold-dust and Ashes (I933) provided the Australian public with nationalist images of their own kind making good in the territories (Dixon 200I). Idriess and Clune in particular had already gained fame detailing life in the Australian outback. Such tales were peopled with heroic Australians and primitives "rightly" dispossessed of their land, in the perspective of these writers (Strauss 1998). Turning their pens toward the territories of Papua and New Guinea (separate until after World War II) required little modification. For Clune, it was simply another opportunity to celebrate Australian enterprise. Others, like Booth, followed many of the literary 
tropes found in Australian bush realism but relied on their own experiences for the narrative. Like many historical texts, these tales lack firsthand accounts of cannibalism as a practice but portray the inhabitants of the valley as cannibals nonetheless. In doing so, these writers naturalized the local people as part of the wild environment from which prospectors hoped only to acquire gold. For the audience, including would-be miners, the authors described the possibilities of gold and the means of its acquisition, creating a "spectacle" that engaged individuals and investors alike (Tsing 2000). In their often-sensational narratives, they provided a personal perspective on prospectors' relations with the Biangai.

\section{Mountains, Gold, and Cannibals}

Such a lot of nonsense is written about New Guinea by would-be adventurers that if one told the things that are really true it would only sound like another tall story.

- DORIS BOOTH, QUOTED IN

The Register, I 3 MAY 1928.

Doris Booth recounted her own unique struggles against the environment and resident "cannibals" in the book provocatively titled Mountains, Gold and Cannibals (1929). Having remained behind while her husband, Charles "Yorkie" Booth, went ahead to stake a claim, she led a group of carriers along the steep mountain paths. In 1924, Booth, the first female miner and nurse to enter the Bulolo Valley, made the arduous trek up from Salamaua to the Biangai village of Kaisenik. Arriving there she encountered her first "cannibalistic" image. Until this point in her account, cannibalism had mostly been a topic of conversation, in warnings that carriers and other diggers passed along to her. But from here on, the stories and personal experiences became entangled. Noting that Kaisenik villagers had recently engaged in warfare, Booth described the village as she witnessed it: "They had been at war a couple of days before our arrival; and there were trophies-gruesome ones-lying around their houses. I saw bones and skulls lying all over the place-without doubt the remains of a cannibal feast! Some of the houses were decorated with these terrible souvenirs of the chase, and of the feast that followed. Here there was some attempt at displaying them, but in some of the houses the bones were just thrown on the floors. In one house a kind of shelf was erected to support a row of grinning skulls!” (I929, 72). Later, having been offered a sample of this feast, she wrote: 
I determined to see it, and Usendran [her assistant] went off with one of the interpreters, and returned with a portion of a human foot! Proudly Usendran displayed the exhibit. I looked long enough to see that the skin was crackled on the foot, and that it looked like a piece of pork.

Then I began to feel very queer, and I waved Usendran away, telling him to bury it. Usendran looked upon it as a huge joke. He had been a cannibal himself, and there was a possibility that the gruesome foot was "buried," but not in the way that I had ordered. (Booth $1929,73-74$ )

Booth's training as a nurse gives a certain degree of credibility to her assessment of human remains, and Biangai today corroborate such tales, describing enemies in warfare, such as the Watut, as "our food." In 200I, one man described to me the practices of his forefathers as they encountered Watut men for the first time, killing them and returning home with the head and long bones for consumption in the village. He had not witnessed or participated in such acts; in all my interviews, no one had. But they all believed strongly in this account of the past.

While resting in Kaisenik, Booth sought local laborers among these "cannibals" to help her finish the final two days of her journey. She wrote of her recruiting efforts among the Biangai: "Nobody had ever succeeded in getting recruits here before, two that I signed on being the first to ever sell their liberty" (1929, 73). She credited her success to her trade items, for "no hawker ever displayed his wares more insinuatingly or winningly than I to these cannibals of the hills. How their eyes glistened covetously when they saw the trade knives and tomahawks!" (Booth I929, 73). As with other mining communities (Nelson 1976), it was in such ways that the Kaisenik, and probably all Biangai, were enticed into labor. However, their relationship with the growing mining community was one of tension and subordination. Having succeeded in persuading more of them to help her finish her journey to her husband's claim along the Bulolo, Booth complained that they "had no idea of the art of carrying. . . . I feared for the stores ... the Kanakas were so wild and seemed to treat the packs with such contempt" (1929, 74-75). Throughout the final stage of her journey she wrote of their "uncivilized" ways-for instance, how easily they would abandon the labor at hand to chase after some "poor beast" in the forest, forsaking the order of her lines. The locals could not imagine the frustrations and anxieties of this young Australian woman, nor could she imagine theirs.

On the morning of the second day, Booth's Biangai carriers threatened to abandon her and her stores, despite her yelling, "No come, no pay" 
(1929, 78). In what she called a "desperate bluff," she pressed her revolver against the body of their leader and threatened to shoot him first, implying that others would follow. While her colorful account is replete with the prejudices of her time, it reveals the antagonistic relationship that communities established with miners-enticed by their goods, but even more reluctant to "sell their liberty" (Booth I929, 73). Hank Nelson documented the variety of ways in which these early encounters occurred (I976), and many of the prospectors who found their way to the Bulolo Valley had prior experience along the Waria and the Lakekamu rivers. While this was Booth's first prospecting trip, she was not new to the islands, and (at least in her account) she closely followed the example set by other prospectors in other areas. More importantly, according to her story, Booth had fruitfully engaged the Biangai, revealing distinctions between herself and these "cannibals." She was civilized, ate proper food in the proper fashion, and carried out her tasks with purpose and not fancy.

Cannibalism remained a powerful image for Booth throughout her stay. After she arrived at her husband's camp she wrote of her struggles with carriers, the relationship that she established with some of them, and the events that peppered the early days of the Bulolo gold rush as she tried to maintain a household and tend to the sick. The monotony of working the goldfields was occasionally interrupted by gatherings, typically around Christmas. During one Christmas dinner she and her husband played host to a group of five fellow prospectors. As the guests gathered, "One item of local news filtered out to the kitchen was that one of our boys, who had been missing, had been killed by our nearest neighbors, the local Kanakas. Probably they had been short of a Christmas dinner!" (Booth I929, I I9). This "news" was in fact never confirmed, but because absent laborers were seen as incapable of easily running away to distant lands, their entering the local food chain seemed somehow a more plausible explanation. The trope of cannibalism always retains distinctions between known and unknown, self and other. For these writers, their own "boys" were never recently associated with such practices (though certainly it was considered a part of their pasts), nor were the laborers of other prospectors. Instead, the cannibal always took the form of the local communities on whose land Booth and her husband mined.

Later, during her first trip to the Edie Creek area, just after the discovery by Royal and Glasson in I926, Booth took in the scenic view from atop the mountain path: "Here and there the carpet of green or blue was 
broken by these evidences of Kanaka habitation or industry. Now and again an ant crawled across the picture-a Kanaka or his Mary walking from hut to hut, or some primitive husbandman homeward plodding his weary way-perhaps with his neighbour's head in his bag!" (I929, I 58 ). While crediting them with some industrious traits, Booth saw the Biangai as leading weary lives and eking out a difficult living, but she always considered them likely suspects of cannibalism. They were part of the landscape that Booth witnessed, working in their gardens and casually eating their neighbors. Although evidence regarding the degree to which cannibalism was practiced seems scant, the images were quite powerful and were readily consumed by Australians and others anticipating the wealth to be won from inland New Guinea. They also served to justify the violence committed against the Biangai communities in later years.

\section{Kaisenik Killings}

The images that engaged early miners were those of solitary individuals overcoming great difficulties of the environment in order to find gold. Cannibalism fit well into this struggle; as a parallel narrative to conquering the mountains and winning the gold, the miners also overcame that most extreme of other. For instilling the dangers of cannibalism in the hearts and minds of the white community who were settling along the Bulolo, however, none could compare with the events that came to be known as the "Kaisenik Killings" of I926-1927. Widely reported and a common feature in miners' travelogues, the Kaisenik Killings remain a significant event for contemporary figures in and around Wau and feature centrally in discussions with Biangai about the arrival of whites.

Conflicts began to emerge as small-scale miners rushed into the valley, finding their way along indigenous paths that pass through Biangai villages. Assistant District Officer Samuel James Appleby reported that during a 1924 patrol to the goldfields, Biangai complained of thefts committed by carriers (Appleby 1927). According to Appleby, because the small group of prospectors on the field had experience in other parts of the territory (see Nelson 1976), they quickly responded with compensation and assurances that quelled Biangai anger. Friendly relationships were ensured by establishing trade ties. Appleby later reported that no further trouble took place at the time.

The gold rush of 1926 was quite different and further shaped perceptions of the valley as not only rich in gold but also full of cannibals. Fol- 
lowing the announcements of the goldfield throughout the press, several hundred prospectors of various experiences sought their fortune. They made their way to Rabaul, and then on to Salamaua where they acquired the necessary supplies and the laborers to carry them. As over a thousand indentured laborers passed through the Biangai villages of Wandumi, Kaisenik, Pinaleng, Salankora, and Lambaura (modern-day Wandumi, Kaisenik, and Biawen), coastal laborers made a habit of raiding Biangai gardens, often taking pigs and produce as well as cutting down betel-nut and pandanus trees (Willis I977a, I977b). ${ }^{5}$ These problems resulted in violence between December 1926 and January 1927, when a group of three Biangai brothers responded by attacking and killing two carriers from coastal Waria. In the events that followed, more carriers were attacked, three were killed, arrests were attempted, police reinforcements and colonial officers were called in, Biangai villages were burned, their gardens were destroyed, and a number of Biangai were killed. While Booth had tried to purchase Biangai liberty, the violence of 1926-1927 brought them forcefully under colonial control.

Reports of these events vary greatly, but like those of so many other incidents throughout the territory, they served the dominant moral message. Booth's account briefly reported that "the local kanakas had killed and eaten five indentured labourers" (I929, I6I). 6 More sensationally, she wrote of the eventual arrests, and stated that after losing a number of men to the fighting, "the cannibals were found cutting up their own dead, ready for the table, when the expedition returned to collect the bodies for burial. The cannibals did not believe in waste" (Booth 1929, I62). Hers is the only account of endo-cannibalism I know of for the area.

Idriess, noted for his elaboration and fanciful rendition of history, speculated about messages sent along the "bush wireless"-in other words, drummed messages. ${ }^{7}$ In one of his many moments of speculative zeal, he quoted the bush wireless messages as saying: "The bush kanakas are short of meat!" (I933,I5I), and later: "Plenty of meat is coming-take it!" (Idriess I933, I 52 ).

Cannibalism was not unique to this event, Idriess wrote: "The whites knew that the carriers who disappeared could not all be deserters, for among them were men from overseas. These had nowhere to desert to. If they took to the bush they knew their certain fate" (I933, I 52). In reference to the events that provoked such outrage, his account tells of three headless men found by Sergeant Joseph M Bourke: "Their bodies quite warm"; but before Bourke could return with a larger party, the bodies had vanished: "the cannibal men came eagerly back and snatching up their vic- 
tims, carried them to the host salt water springs quite near the track and their cooked them" (Idriess I933, I 54).

With respect to the first attack against carriers, the media were relatively silent, almost casually reporting the deaths. One of the earliest accounts (in the Adelaide Advertiser on I I December 1926) reported that "news has been received at Edie Creek gold fields that the bodies of two carriers had been found shockingly mutilated in a ravine near a small native village ... one body had been almost beheaded." The account follows Mining Warden John D McLean's description of events noted in an official press release. Early media coverage of the January 1927 deaths initially followed this official press release, which does not mention cannibalism, reporting only, "The Warden said that the village natives are of a very low type" (NAA I927). However, more sensational accounts appeared as the violence escalated and seemed to threaten the future of the area. The Daily Guardian headline on 27 January 1927 read, "Cannibals Attack Porters on Govt. Works," and the article stated, "The bodies were shockingly mutilated, as all that was found was portion of stomachs and shoulders. Evidently the rest of the bodies had been carried away, probably to provide a cannibal orgy and sing sing." Again, there was no confirmation, but the image further connected the goldfields with cannibals. Other elaborations, though less sensational, achieved a similar portrait of moral superiority, calling the local population a "vindictive tribe" (Sun News-Pictorial, 22 Jan 1927), while most echoed the official media release depiction of the natives as being a "very low type" (see, eg, Sun News-Pictorial, 22 Jan 1927; Register, 22 Jan 1927).

Today, Biangai describe these events as warfare between themselves and the white community, warfare that had not so much alienated land as it had subverted Biangai political authority and subsequently redefined their relations to each other. In the years that followed the Kaisenik Killings, their men's houses were systematically burned (see Martin 1992), ending what Biangai now refer to as an independent Biangai government (Haus Parliament bilong mipela). Within ten years, the troublesome villages that became Kaisenik were no longer thought of as a threat. Cannibalism-a practice thought to be so natural and engrained-had simply vanished. In a short article in Pacific Islands Monthly entitled "Kaisenik: Model Village in Place of Cannibal Den," the unnamed author recounts a visit "with the object of making a mental comparison with the past" $(\mathrm{I} 936, \mathrm{I} 5)$. After reiterating how "natives incurred the wrath of the miners by killing and eating their native carriers," the author described the village as having completed a moral transformation: 
The new village lies in a hollow, alongside a tributary of the Bulolo River, and is surrounded by native gardens of sugar cane and kau-kau (sweet potato). Pigs run about the village and rear the numerous offspring under the grass roofed houses. The staccato crow of a domestic rooster would indicate that the love of poultry is not confined to the American Negro. The peacefulness of the agrarian scene is completed by the village church, which is the largest building in the place.

In what was once a cannibal village not a warrior remains. The warriors that might have been are away working on the gold claims of their conquerors. The village is in the keeping of the old men, women and children. (Pacific Islands Monthly, I936, I 5)

The work that was begun during Doris R Booth's day was completed, as indentured labor was now the rule and not the exception. Here, in its absence, cannibalism continued to create images of the other, transformed not by their own agency, but by colonial and mission forces. The natural mineral wealth entered circulation not simply through the domestication of value, but also through the subjugation of the other. But how is it that such an image persists? I do not believe we can write it off as the product of ongoing violence in Papua New Guinea. While it is certainly a concern, violence alone does not beget the image of primitivism, particularly when guns, advanced technical and mechanical means for mineral extraction, and an educated leadership and working class are part of the picture. Instead, we can see the perpetuation of this imaginary in local development discourses, and in postcolonial labor and compensation practices.

\section{Consuming Others or Consuming Yourself}

As a result of eighty years of mining, and contrary to David Hyndman's view (1994), the Biangai are not just now beginning to undergo a transition from kinship-based modes of production to a capitalist-based one. Instead, compared to other inland communities of Papua New Guinea, by the end of the I930s Wau had become more than an outpost of gold miners and missionaries. The developing township included a movie theater, a swimming pool, telephones, stores, a brewery, tennis courts, a rifle range, motor vehicles, a Masonic temple, a hotel, and regular air service. Euro-Australians entertained themselves with formal balls, musical societies, and visits from Santa Claus. On the edge of this emerging European outpost, the Biangai witnessed a great transformation of their valley, as 
well as the emergence of gold and timber as powerful resources in a changed political economy. Following World War II and the depletion of the valley's easily accessible ore, logging drove the economy until PNG independence in 1975. The industries held by New Guinea Goldfields were partly nationalized into the hands of the Biangai Development Corporation, including buildings, leases, and equipment. But after independence, the market for timber eased, and Biangai management of former colonial enterprises proved ineffective. Aspirations for managing their own enterprises remain, and Biangai and non-Biangai continue to line the streambeds looking for any last remnants of the gold rush. However, relatively little is to be found, and businesses lack the capital and markets necessary for success. The Biangai have been left wondering why things changed so dramatically under their leadership.

For the colonial township of Wau, controlling the "cannibals" in the area was central to the emergence of the community and the extraction of gold. Its becoming an administrative center coincided with increased government presence and, more importantly, the advent of commercial flights that circumvented perceived cannibal villages. Today, this town has fallen into a state of near chaos, with weekly robberies, large settler populations, pervasive alcoholism, marijuana use, and a state of ongoing violence that has lead Biangai to refer to this closest administrative center as a "cowboy town." While some debate economic and government responsibilities, others, like the miners before them, blame the lack of development and their own failure on a past of cannibalism. Cannibalism figures not only into precolonial and colonial warfare but also into Biangai cosmology. The cannibalistic imaginary overshadows gold and coffee, and, in the eyes of some, the township is condemned to perpetual malaise until the past is accounted for, while others are allowed to prosper.

Those who have established rights in the Hidden Valley project being developed by Morobe Goldfields (now run by Harmony, of South Africa) ${ }^{8}$ do stand to benefit in ways that their ancestors could not. However, not much has changed regarding who owns the means of production and who retains ultimate rights in the mineral resources. Under PNG mining laws, recognized landowners derive benefits from access routes and compensation for damage to surface resources. Mineral resources ultimately remain the property of the government. The Biangai groups identified as rightful beneficiaries (from Winima and Kwembu villages), like landowners throughout Papua New Guinea, find themselves on the margins of project development and production. Those Biangai without such legal 
claims are even further removed. Many might work for the mine, and some will develop small businesses in support of the company and a growing mining community, but most try to establish their rights to compensation payments in terms of Biangai cosmology and history.

In the next section I consider the relationship between gold and cannibalism, not as a threat of violence, but as it informs local models of production. Gold's circulation does in fact permeate the economy (like oil), but its distribution is not uniform. As indicated above, while some Biangai stand to gain, others will not. And even those who are recognized as stakeholders and work for the mine lack real power over the day-to-day operations. A dialogue has ensued (among Biangai themselves and between Biangai and the mining industry) to explain these differences in access to gold.

\section{Cannibalism and Production}

Discussions of cannibalism are not uncommon in the discourse surrounding Biangai views of their past. According to Biangai cosmology, the first man was a cannibal (Martin I992). He was strongly disliked for consuming members of his own family. In retribution, he was killed and buried on a hillside between two contemporary villages, and it was from his body that the first yams were formed (for similar personifications, see Fortune I963 [1932]; Harrison I982; Tuzin 1972). These yams were revealed to his sisters, to whom he had promised to return in a form essential for their survival. The production and consumption of yams is heavy with meaning, revealing the ultimate source of productive agency to be established through relationships with ancestral agents. Such agents are at the heart of Biangai failures and successes, whether it be yams or gold.

Throughout Papua New Guinea, yams are often symbolically linked to human beings. For example, Reo F Fortune described the Dobuan emphasis on yams as being like humans but inhabiting an underground realm through which they move and grow. Dobuans, he wrote, "class yams with his own people as personal beings" while excluding whites from this same category (Fortune 1963, I09). Donald Tuzin likewise noted this analogy for the Arapesh, adding the significant role that yams play in masculine group identities. Beyond their phallic associations, Arapesh yams mirror human genealogy. At marriage, both men and women inherit a set of seed yams, from which they will plant distinct crops. This distinction is maintained until the first child is born. Tuzin wrote, "Eating yams is a 
mystical as well as physical act, and in sharing their ancestral yams a married couple is engaging in a form of spiritual communion" $(1972,235)$. The importance of maintaining the distinctiveness of each ancestral source is significantly reduced once their first child is born. At that time, "the spirits of their yams have fused" (Tuzin 1972, 236).

The Biangai seem relatively less concerned about maintaining the distinctiveness of the seed yams, but they still emphasize the importance of passing such resources among extended family members. Men and women will often ask their families for seed yams to add to their own, and these they plant together in family gardens that likewise evoke ancestral relationships. Seed yams mark a genealogical connection to prior seasons and prior gardens, but they are planted in soil that likewise links men and women to their ancestors. The right to consume yams is distributed broadly throughout an extended network of kin, with the newly harvested crop being sent back and forth throughout and between villages. This distribution allows for great participation in the shared substance of the cognatic lineage group.

While yams continue to play a central role in the Biangai communities of Winima and Elauru, growing coffee and working for the gold mine increasingly take precedence in the creation of value. This is particularly noticeable in Winima, where many of the men work as full-time or contract laborers in the mine. Winima villagers reduce the work spent on subsistence crops, including yams, while Elauru village celebrates their continued adherence to the practice of planting them, although they acknowledge that the numbers are not as great as before. ${ }^{9}$

In the shadow of ongoing mining for gold (and the decreased significance of yams in the wider economy), some Biangai have questioned the "true meaning" of the first man's promise to his sisters. Perhaps something else was intended? Perhaps more was meant in his promise? Perhaps the body of the first man gave rise to gold as well? The interpretation that these questions suggests was somewhat common among members of both Winima (inside the lease area) and Elauru (outside the lease area), who did not stand to gain substantially from Hidden Valley's operations or who themselves felt that their rights might be denied. Gold is like the child of an ancestor, I was told by a female landowner from Winima who was concerned about Watut claims in the area (see Halvaksz 2003; see also Biersack 1999; Rumsey and Weiner 2004). She composed a song expressing her sadness about this possibility and the likelihood that ancestral spirits would carry the gold away. In her song, the gold was the child of a set 
of ancestors that inhabit the range now occupied by the mine. These ancestors could decide to leave with their children if the mining agreement does not follow proper genealogies. But for her it was not simply a metaphor. The ancestors are real, as is their contribution to the economic livelihoods of the living. Such gold can only be consumed by those with rights to consume it.

In Elauru, alienated from the mining lease at Hidden Valley, the villagers struggled to understand why gold was not found on their lands, and some sought to extend rights to that at Hidden Valley through assertions rooted in Biangai cosmology. One Elauru friend described the cosmological link from the first man and asserted that his promise to his sisters referred not to yams but to gold. Elaborating on this point, he noted scientific data that he had gleaned from conversations with geologists and a brief stint as a laborer on the mine site, rhetorically asking, "Geologists say that gold comes back this way, now where does it go?" The gold, he told me, is not the child of this recent ancestor, as claimed in Winima and Kwembu, but the product of the first man who was buried near Elauru, and he argued that this is what the geological data indicated.

At his death, the first man promised a garden, one that would attract many and provide for all Biangai. My friend noted that gold certainly filled this prophecy better than yams. For an Elauru man, alienated from the Hidden Valley project, reflecting on a history of resource extraction, the promise was for something greater: "He foretold of the gold, and on these pine trees, Klinkii pines and Hoop Pines, it [yams] was a metaphor." Development opportunities were plenty, and all were rightfully theirs to claim, but none had come to fruition. Gold offered the most potential, as Biangai had witnessed the transformation of their valley under its guidance. However, it had yet to transform their lives in a substantial way, raising concerns about what negligence had been committed, or as one group of village trade-store owners complained, "What kind of sickness do the Biangai have?" The answer most often offered was a moral one-that the consumption of flesh by their ancestors held them in check, prevented development, and would do so until amends had been made (for similar analyses, see Robbins 2004; Smith I994).

\section{Apologizing for CAnnibalism}

Early in the morning, as some friends and I walked to Wau for supplies, we fell in line behind a group of middle-school students making their daily 
trek to the community school in the village of Kaisenik. As we turned the final corner before the school, descending toward the first houses of the village, one of my companions took note of a printed secondhand T-shirt worn by a young man in front of us. He tapped my shoulder and pointed, asking if I thought it was a reference to the Biangai. The shirt was typical of the secondhand clothes that enter the global flow of discarded items from Australia, Europe, and America (see Hansen 2004). Slightly worn, the fading design on the back depicted a book cover from a classic B-grade novel. "Cannibals" was the only legible word, with an image of a dark figure looming over a young white teenager-female, if my memory serves me. They pressed me for information, and, at the time, thinking nothing of the image, I explained how teenagers in America favor such clothing, trying to get across the idea of "retro" as reviving the fashions of the past. The image, I explained, was taken from the cover of a work of fiction. I assured him that it was not necessarily about the Biangai, or Papua New Guinea, and it was certainly not a true story. Our conversation faded as we passed through the village, stopping to chat here and there on our way toward Wau. As we walked on, my companion, still thinking about this image, commented that local church leaders were going to apologize for such practices, and that by doing so they might make development possible.

Plans had been underway for some time to apologize (tok sori) to those whose ancestors had died on this land. Local church leaders wanted to invite Watut communities to a feast and make this apology in hopes of restoring the productivity of the land. While this feast never eventuated, the idea remained a powerful way to explain failure and the regression of the township of Wau. Biangai efforts at most things, whether managing stores and businesses, growing coffee and other cash crops, or attracting international mining companies to their land, always seemed to fall short, if not fail. At the time of my fieldwork in 2000-2002, Hidden Valley was in a seemingly endless phase of exploration, adding to local anxiety. Many felt that the ground itself was against them, as an active agent of past wrongs.

One sunny afternoon, a senior Winima man and I were discussing this dilemma of development when he started telling me his version of Biangai history. The ground, he explained, is the source of the problem, because it was on this ground that men died in precontact warfare, and it was on this ground that Biangai fought and consumed others. Coffee will never grow here, he said, nor will development come to Biangai who do not 
acknowledge this error of their ancestors. He laughed off the effort of yet another company to try and develop coffee along the Bulolo. Like the mining efforts, and many Biangai attempts to do the same, he felt it would surely fail.

Embedded in these Winima and Elauru images of gold's purpose is a dialogue about their past and future. The gold at Hidden Valley, in their view, rightfully belongs to the Biangai (especially the two villages within the lease area, Winima and Kwembu) and not to neighboring Watut. It is a gift from their ancestors, if not from the first man, and the Biangai should prosper from its extraction. However, attributions of Biangai failures and Wau's decline derive from a reversal in meaning, the product of missionization and pacification. The positive productive agency that might have once been attributed to warfare and the practice of cannibalism is reversed, giving a negative moral weight to these practices and a negative effect on the productivity of the land. Ultimately, it requires a reconsideration of relations with ancestors. Because they were once cannibals, a new imaginary denies them access to agencies they once controlled.

\section{Why Papua New Guinea Is Not Venezuela: THE VIEW FROM WaU}

In the appropriately short-lived television drama Baywatch Nights, David Hasselhoff's daytime lifeguard character and a female companion spent their evenings engaged in detective work, primarily investigating paranormal events more suitable for The X-Files or other such science fiction program. In one episode, entitled "Terror of the Deep" (Bonann I996), the detectives were confronted with a sunken ship recently arrived from the Papuan coastline. A female survivor reported that the ship had been attacked by a large, cannibalistic, yet protective spirit called Ajogun. This spirit sought to reclaim an ancient gold amulet that had been fashioned by primitive tribes, presumably around Port Moresby. ${ }^{10}$ While filled with many inaccuracies, the episode revealed an ongoing conceptualization of the primitive state. In Baywatch Nights, Papua New Guinea was a haunting image, inhabited by Stone Age tribes concerned with ancient artifacts and not modern exchange value. However, while continuing to naturalize the desires of the other, the image was more complex in that, like the Biangai today, this ancestral ghost was concerned with gold and its theft by others who lack rights to it.

Ideas about cannibalism continue to circulate, both internationally and 
locally, in close association with gold. The cannibal ghost of Baywatch Nights reminds us of the power that this imaginary has for international consumption, and historical texts provide insight into the formation of such images. But local ideas about cannibal pasts likewise reveal an economy driven as much by questions of morality as by desire for wealth. While we can argue that in places like Venezuela resources such as oil are symbolically converted into a common currency, defining the state as it circulates, gold in Papua New Guinea tells a different story. While its impact on the broader PNG economy is widespread, its circulation remains uneven, highly localized, and extremely temporary, as gold rushes and gold mines ebb and flow. The imperfect distribution likewise results in an inconsistent domestication of value. It is this inconsistency that the Biangai seek to explain.

In the villages around Wau, responses to the sporadic presence of gold always raise questions about resource rights and the meaning of gold. Early miners imagined the "cannibals" around them as potentially consuming their flesh and that of their laborers, should they fail to be watchful, bold, and aggressive, even as they delved into the earth's surface extracting gold. The natural body and social body were clearly distinguishable. While the Euro-Australians fit solidly within the social, the natural encompassed mountains, gold, and cannibals. For the Biangai the distinction between the natural and social is less certain, imagining a landscape of ghosts and spirits embodied in yams, in gold, or in both.

Unlike Venezuelan oil, the circulation of PNG gold not only permeates the economy of the modern nation but does so while still infused with history and local meanings that continue to link it to ideas of an other, including the cannibal (even when that other is the self). Around Wau, as in other areas of mineral production (see Rumsey and Weiner 2004), industrial mineral production and cosmological production are merged. Gold might be domesticated in places like Wau, where it circulates among international mining companies, designated beneficiaries, government officials, small-scale miners, criminals, and communities, but it does not do so unencumbered from rich historical meanings and local cosmologies, including ideas about cannibals, both real and imagined.

* $* x$

The ethNOgRaphic material presented here is drawn from fieldwork conducted between November 2000 and March 2002. Funding for this research was provided by dissertation research grants from the National Science Foundation, 
Cultural Anthropology Program (BCS-0003927); the Wenner-Gren Foundation for Anthropological Research (GR 6724); and the Graduate School, Grants for Research Abroad, University of Minnesota.

\section{Notes}

I Numerous authors have already begun to address this question. For instance, Hank Nelson's work on early gold mining highlights the particularity of each encounter as government officers and gold miners found their way into the islands (1976). Eugene Ogan has explored how the plantation economy set the stage for the Bougainville conflict (I996).

2 Elauru villagers have been involved in a small-scale conservation area and research station in association with the Wau Ecology Institute (see Halvaksz 2005).

3 On the Biangai, see also Burton 1996a, 1996b, 2000a, 2000b; Chinnery I928; Martin 1992; Martin and Oullette I98I; Mitio I98I; and Oullette 1987.

4 Elsewhere I have also considered the broader media portrayal of cannibals and gold during the I920s and I930s (Halvaksz 2005).

5 Ian Willis summarized the history of the Kaisenik killings (1977a, 1977b).

6 In a report submitted by Appleby, the first two bodies were said to have been buried by one of the mission helpers (1927). No report of cannibalism exists for the other three deaths.

7 James Sinclair wrote, "When I was living in Wau in 1948, old hands assured me that they had spun Jack Idriess a lot of colorful yarns, many of them true, others not" (1998, 30). Charles Wells, chairman of New Guinea Airways, likewise expressed doubts about the quality of both Clune's and Idriess's works, noting in a letter to the editor of Pacific Islands Monthly, "What fills me with depression is that crude writers of the type of Idriess and Clune should be the only ones game enough to tackle this colossal story" (Wells I939).

8 At the time of my fieldwork (November 2000-May 2002), the Hidden Valley lease was being developed by Aurora Goldfields.

9 In 200I, Elauru villagers planted 36.82 mounds per household, while Winima villagers planted $\mathrm{I} 8.85$ mounds per household.

Io Actually, Ajogun is a group of malevolent spirits within the Nigerian Yoruba religious cosmology (Pemberton 1987).

\section{References}

\section{Advertiser (Adelaide)}

I926 New Guinea Natives Murdered. Lax Administration Alleged. I I December. 
Appleby, Samuel James

I927 Report on the Native Disturbances, Biololo (Rabaul) Area. National Archives of Australia 1927/728.

Arens, William

I979 The Man-Eating Myth: Anthropology and Anthropophagy. New York: Oxford University Press.

Biersack, Aletta

1999 The Mount Kare Python and His Gold: Totemism and Ecology in the Papua New Guinea Highlands. American Anthropologist Iог (I): 68-87.

Bonann, Gregory, director

I996 Terror of the Deep. Baywatch Nights, Episode 23. Written by Chad Hayes and Carey Hayes. Aired 29 September 1996. Syndicated.

Booth, Doris R

I929 Mountains, Gold and Cannibals. London: Morrison and Gibb, Ltd.

Brown, Paula, and Donald Tuzin, editors

I983 The Ethnography of Cannibalism. Washington DC: Society for Psychological Anthropology.

Burton, John

I996a Aspects of the Biangai Society: The Solorik System. Hidden Valley Project, Working Paper 3, March. Prepared for CRA minerals. Canberra: Pacific Social Mapping.

1996b Early Colonial Contacts among the Upper Watut and Biangai Peoples from I 895 to the First World War. Hidden Valley Project, Working Paper 6, April. Prepared for CRA minerals. Canberra: Pacific Social Mapping.

2000a Settlement History of the Southwestern Biangai and Catalogue of National Museum Site Code. Hidden Valley Project Working Paper I 2, August. Wau, PNG: Morobe Consolidated Goldfields Ltd.

2000 b First Contacts between Outsiders and the Watut and Biangai People of the Wau and Bulolo Area. Hidden Valley Project Working Paper I3, October. Wau, PNG: Morobe Consolidated Goldfields Ltd.

Chand, Satish

2003 PNG Economic Survey: Some, Albeit Weak, Signs of Recovery. November. Online: <peb.anu.edu.au/pdf/chand 2003.htm>

Chaplin, Charles, director I925 The Gold Rush. Feature film. Charles Chaplin Productions.

Chinnery, E W Pearson

I928 Natives of the Waria, Williams and Bialolo Watersheds. Anthropological Report 4. Territory of New Guinea. Canberra: H J Green.

Clune, Frank I952 Somewhere in New Guinea. New York: Philosophical Library. 
Coronil, Fernando

I997 The Magical State: Nature, Money and Modernity in Venezuela. Chicago: University of Chicago Press.

Daily Guardian (Sydney)

I927 Natives Killed at Bulolo: Cannibals Attack Porters on Govt. Works. I4 January.

Demaitre, Edmond

I936 New Guinea Gold: Cannibals and Gold-seekers in New Guinea. Boston: Houghton Mifflin Company.

Dixon, Robert

200I Cannibalizing Indigenous Texts: Headhunting and Fantasy in Ion L Idriess' Coral Sea Adventures. In Body Trade: Captivity, Cannibalism, and Colonialism in the Pacific, edited by Barbara Creed and Jeannette Hoorn, I I 2-I 25. New York: Routledge.

Fortune, Reo

I963 Sorcerers of Dobu: The Social Anthropology of the Dobu Islanders of the Western Pacific. Revised edition. New York: E P Dutton \& Co, Inc. First published in 1932.

Goldman, Laurence R

I999 From Pot to Polemic: Uses and Abuses of Cannibalism. In Goldman I999, I-26.

Goldman, Laurence R, editor

I999 The Anthropology of Cannibalism. Westport, ст: Bergin \& Harvey.

Halvaksz, Jamon

2003 Singing about the Land among the Biangai. Oceania 7 (3): I 53-I 69.

2005 Re-Imagining Biangai Environments: Mining and Conservation in the Wau Bulolo Valley, Papua New Guinea. PhD dissertation, University of Minnesota.

Hansen, Karen Tranberg

2004 Helping or Hindering? Controversies around the International Secondhand Clothing Trade. Anthropology Today 20 (4): 3-9.

Harrison, Simon

I982 Yams and the Symbolic Representation of Time in a Sepik River Village. Oceania 53:I4I-I62.

Healy, Allan Michael

I967 Bulolo: A History of the Development of the Bulolo Region, New Guinea. Canberra: New Guinea Research Unit, Australian National University.

Hyndman, David

I994 Ancestral Rain Forests and Mountains of Gold: Indigenous Peoples and Mining in New Guinea. Boulder: Westview Press. 
Idriess, Ion Llewellyn

1933 Gold-dust and Ashes. Sydney: Angus \& Robertson Ltd.

Lindenbaum, Shirley

2004 Thinking about Cannibalism. Annual Review of Anthropology 33: 475-498.

Martin, Jean-Claude

I992 Le changement social et la question de la resistance aux techniques nouvelles chez les Biangai de Papouasie, Nouvelle-Guinea. PhD dissertation, University of Montreal.

Martin, Jean-Claude, and Francoise-Romaine Oullette

198I Golden Future? The Dilemma of the Biangais of the Wau Valley, Morobe Province. Cultural Survival 7:50-58.

Mitio, Ngawae

198I Biangai Marriage and its Relationship to Kinship and Property: The Case of Werewere Village, Wau District. Honours sub-thesis, University of Papua New Guinea: Port Moresby.

NAA, National Archives of Australia

I927 Salamaua-Bulolo Arnei Road, New Guinea, Attacks by Natives. NAA: P $1927 / 728$.

Nelson, Hank

I976 Black White and Gold: Goldmining in Papua New Guinea, I878-I930. Canberra: Australian National University Press.

Obeyesekere, Gananath

I992 "British Cannibals": Contemplation of an Event in the Death and Resurrection of James Cook, Explorer. Critical Inquiry I8 (Summer): 630-654.

I998 Cannibal Feasts in Nineteenth-Century Fiji: Seamen's Yarns and the Ethnographic Imagination. In Cannibalism and the Colonial World, edited by Francis Barker, Peter Hulme, and Margaret Iversen, 63-86. Cambridge: University of Cambridge Press.

200 I Narratives of the Self: Chevalier Peter Dillon's Fijian Cannibal Adventures. In Body Trade: Captivity, Cannibalism and Colonialism in the Pacific, edited by Barbara Creed and Jeannette Hoorn, 69-II I. New York: Routledge.

Ogan, Eugene

I996 Copra Came before Copper: The Nasioi of Bougainville and Plantation Colonialism, 1902-1964. Pacific Studies 19:3I-5I.

Oullette, Francoise-Romaine

I987 Rapport de sexe et developpement capitaliste chez les Biangai de la region de Wau. PhD dissertation, University of Montreal. 
Pacific Islands Monthly

I936 Kaisinik: Model Village in Place of Cannibal Den. Pacific Islands Monthly 7 (3): I 5-I6.

Pemberton, John

I987 Yoruba Religion. In The Encyclopedia of Religion, editor in chief, Miracea Eliade. I 5:535-538. New York: Macmillan.

Register (Adelaide)

I927 New Guinea Natives: Attack on Warden's Party. A Few Casualties. 22 January.

I928 Guinea Gold: Mrs. Booth of Bulolo. I3 May.

Robbins, Joel

2004 Becoming Sinners: Christianity and Moral Torment in a Papua New Guinea Society. Berkeley: University of California Press.

Rumsey, Alan, and James Weiner, editors

2004 Mining and Indigenous Lifeworlds in Australia and Papua New Guinea. Second printing. Wantage, uк: Sean Kingston Publishing.

Sahlins, Marshall

I976 Culture and Practical Reason. Chicago: University of Chicago Press.

Sinclair, James

I998 Golden Gateway: Lae and the Province of Morobe. Bathurst, Nsw: Crawford House Publishing.

Smith, Michael French

1994 Hard Times on Kairiru Island: Poverty, Development, and Morality in a Papua New Guinea Village. Honolulu: University of Hawai'i Press.

Strauss, Jennifer

I998 Literary Culture 19I4-I939: Battlers All. In The Oxford Literary History of Australia, edited by Bruce Bennett and Jennifer Strauss, I07I 29. Melbourne: Oxford University Press.

Sun News-Pictorial (Melbourne)

1927 Natives Shot: Arrow Attacks in New Guinea, Vindictive Tribe. 22 January.

Tsing, Anna

2000 Inside the Economy of Appearances. Public Culture I2 (I): I I 5-I 44. Tuzin, Donald

1972 Yam Symbolism in the Sepik: An Interpretative Account. Southwestern Journal of Anthropology 28 (3): 230-254.

Tuzin, Donald, and Paula Brown I983 Editors' Preface. In Brown and Tuzin 1983, I-5.

Wells, Charles Valentine

I939 Letter to R W Robson. 20 November 1938. Australian Archives, Pacific Manuscript Bureau 364. 
Willis, Ian

I977a A New Guinea Outrage: The Killings at Kaisenik I926-I927 (Part I). Journal of the Morobe Province Historical Society 4 (I): 2-IO.

I977b A New Guinea Outrage: The Killings at Kaisenik I926-I927 (Part II). Journal of the Morobe Province Historical Society 4 (2): 7-I6.

\section{Abstract}

The history of Wau township in Morobe Province, Papua New Guinea, is intimately linked with the development of gold mining throughout the region. The site of a series of gold rushes in the I920s, Wau emerged as an early administrative outpost, a town complete with all the trappings of frontier Australian communities. In recent years, Wau has declined, and the Biangai communities reflect on this decline in ways that manipulate both the early colonial discourses and their own. Central to these discussions are images of cannibalism, as the consumption of both living flesh and ancestral landscapes. In this paper I examine the gold rush, how early prospectors conceptualized the colonial project, and what Wau's subsequent decline has meant to the Biangai who now pursue new mining opportunities. I trace these events and perspectives through historical and present-day discourses. Throughout, a fascination with mountains, gold, and "cannibals" is prominent, with Wau emerging out of struggles to conquer these elements of the landscape. Cannibalism remains a pervasive theme in contemporary Biangai discourses as they now try to recreate an era of successful gold mining and community life in and around Wau by overcoming many of the same elements. However, the moral terrain between consuming flesh, consuming land, and consuming gold are differently deployed in order to explain success and failure, and to imagine the nation.

KEYWORDS: gold mining, cannibalism, cosmology, colonialism, first contact, Papua New Guinea, Biangai 